\title{
Efek Senam dan Progressive Muscle Relaxation terhadap Tekanan Darah dan Kadar Gula Darah pada Lansia
}

\author{
Andreany Kusumowardani ${ }^{1}$, Roh Hastuti Prasetyaningsih ${ }^{2 *}$ \\ ${ }^{1,2}$ Poltekkes Kemenkes Surakarta Jurusan Okupasi Terapi \\ Email: rohhastuti@gmail.com
}

\begin{abstract}
Background: The raise of aging population increases the risk of non infectious illness, as hypertension and diabetes mellitus. A comprehensive treatment consists of pharmacological and non pharmacological approach is required to control and cure those diseases. Gymnastics and Progressive Muscle Relaxation as a method of non pharmacological intervention has been denote to be beneficial to control blood pressure and glucose level so that improved the outcome of hypertension and diabetes mellitus. The goal of this study was to determine the impact of gymnastics and Progressive Muscle Relaxation on blood pressure and glucose level of the elderly at Posyandu Lansia Madoh, Boyolali district. Methods: The mothods used a quasi experimental with two group pre-test post-test design. Sample inclusion criteria are elderly aged 50 years or older and willing to be a research sample. As many as 26 sampel that can follow the full intervention.The hypothesis testing uses Mann Whitney Test. Results: Based on the hypothesis test that blood pressure values obtained $p=0.626$ and blood sugar levels $p=0.590$. Thus it can be concluded that gymnastics and PMR are more effective in lowering blood sugar levels than blood pressure. Conclusions: Gymnastics and Progressive Muscle Relaxation has a positive influence on blood sugar levels than blood pressure. So it needs to be done routinely and scheduled in Posyandu Elderly activities in Ngesrep Village, Ngemplak District, Boyolali Regency.
\end{abstract}

Keywords: gymnastics, progressive muscle relaxation, blood pressure, glucose level, elderly

\section{PENDAHULUAN}

Peningkatan populasi penduduk lanjut usia (lansia) terjadi secara signifikan hampir di semua negara termasuk Indonesia. Proporsi penduduk lansia secara global di dunia melonjak dari 13,5\% di tahun 2010 menjadi 14,9\% pada tahun 2025 dan diperkirakan akan terus bertambah mencapai $16,4 \%$ pada tahun 2030 (United Nations Departement of Economic and Social Affairs Population Devision, 2017). Data Kemenkes RI (2017) menunjukkan bahwa penduduk lansia di Indonesia tahun 2017 mencapai 23,66 juta $(9,03 \%)$, dan diprediksi jumlah penduduk lansia tahun 2020 sebanyak 27,08 juta. Provinsi Jawa Tengah termasuk propinsi yang memiliki struktur penduduk tua yaitu menduduki posisi paling tinggi kedua $(12,59 \%)$ setelah DI Yogyakarta.
Salah satu wujud keberhasilan pembangunan di Indonesia adalah meningkatnya jumlah penduduk lansia. Konsekuensi yang dihadapi tidak sederhana, berbagai macam tantangan dalam aspek kehidupan akibat penuaan penduduk telah berpotensi menimbulkan masalah kesehatan pada lansia (BPS, 2017; Strydom, 2005 dalam BagheriNesami et al, 2010).

Sejalan dengan peningkatan usia, fungsi fisiologis mengalami penurunan sehingga resiko mengalami penyakit, khususnya penyakit tidak menular (PTM) lebih besar. Penyakit terbanyak pada lansia di Indonesia adalah penyakit tidak menular dengan prevalensi tertinggi adalah hipertensi $(45,9 \%-63,8 \%)$, diikuti artritis, stroke, PPOK, dan Diabetes Mellitus (Pusdatin Kemenkes RI, 2016). Hampir 70\% kematian di dunia di 
sebabkan oleh PTM (Kemenkes RI, 2018).

Hipertensi dan Diabetes Mellitus (DM) merupakan silent killer karena tidak menimbulkan gejala dan menyebabkan kematian. Penderitanya saat mengetahui sudah terjadi komplikasi seperti penyakit jantung, stroke, dan gagal ginjal (Pusdatin Kemenkes RI, 2014). Prevalensi penduduk dengan hipertensi secara nasional sebesar 30,9\%. Prevalensi hipertensi lebih tinggi pada perempuan $(32,9 \%)$ dibanding laki-laki $(28,7 \%)$ dan prevalensi semakin meningkat seiring dengan pertambahan umur (Kemenkes RI, 2018). Kasus DM, pada tahun 2018 mencapai $8,5 \%$ dari seluruh penduduk di Indonesia. DKI Jakarta menduduki peringkat pertama $(3,6 \%)$ yang disusul oleh Jawa Tengah (2\%) (Kemenkes RI, 2018).

Sebagian besar faktor resiko hipertensi dan DM adalah life style yang tidak sehat yaitu malas melalukan aktivitas fisik, diet yang tidak sehat dan seimbang, stres, serta obesitas. Oleh sebab itu hal terpenting dari pengendalian hipertensi adalah mengendalikan faktor resiko (Anani et al., 2012).

Latihan fisik (exercise) telah sering direkomendasikan untuk mengurangi resiko hipertensi. Latihan aerobik (aerobic exercise) merupakan latihan fisik yang melibatkan otot-otot besar, dilakukan secara ritmis dan berulang-ulang, untuk menjaga fungsi kardiovaskuler (Physical Activity Guidelines Advisory Committee, 2008). Salah satu latihan aerobik yang sering diberikan pada lansia adalah senam. Beberapa penelitian telah mengungkapkan bahwa senam memberikan dampak yang positif bagi penurunan tekanan darah lansia (Trisnanto, 2016; Zulaikha, 2016; Tulak\& Umar, 2017) dan kadar gula darah
(Ramadhani, et al, 2016; Fakhrudin \& Khairunisa, 2012).

Progressive Muscle Relaxation (PMR) adalah teknik relaksasi yang mengkombinasikan latihan napas dalam dengan gerakkan menegangkan otot dan merilekkannya secara bergantian (Kumutha, et al, 2014). Beberapa penelitian telah membuktikan bahwa PMR berpengaruh untuk penurunan tekanan darah dan kadar gula darah (Siswanti \& Kulsum, 2019; Akhriansyah, 2018). Saat relaksasi otak akan menghasilkan gelombang alpha yang menghasilkan keseimbangan mental dan emosional sehingga dapat menekan pengeluaran hormon kortisol, epinefrin dan norepinefrin yang akan mengontrol tekanan darah dan gula darah (Kumutha, et al, 2014). Relaksasi PMR di pandang memiliki keunggulan yaitu mudah untuk dilakukan dan dapat dilakukan dimana saja karena tidak membutuhkan ruangan khusus. Metode relakasi ini cocok digunakan bagi lansia terutama yang mengalami keterbatasan gerak . Tujuan penelitian yaitu untuk mengetahui efek senam dan PMR terhadap penurunan tekanan darah dan kadar gula darah pada lansia di Desa Ngesrep, Kecamatan Ngemplak, Kabupaten Boyolali.

\section{METODE PENELITIAN}

Penelitian dilakukan di Posyandu Lansia Desa Ngesrep, Kecamatan Ngemplak Kabupaten Boyolali. Penelitian ini menggunakan pendekatan kuantitatif dengan desain penelitian quasi eksperimen two group pre-test post-test design. Sampel dipilih dengan menggunakan teknik constitutive sampling. Jumlah sampel sebanyak 26 orang yang dibagi sama besar ke dalam dua kelompok. Sebanyak 13 sampel pada kelompok 
senam dan 13 sampel pada kelompok PMR. Kriteria sampel meliputi: lansia berusia 50 tahun atau lebih, tidak memiliki keterbatasan gerak, gangguan mobilitas, dan penyakit kronis yang akan semakin berat gejalanya dengan latihan fisik.

Intervensi yang diberikan kepada sampel berupa senam dan PMR selama 2 bulan dengan frekuensi 12 kali. Data diperoleh dari sumber data primer yaitu melakukan pengukuran tekanan darah dan kadar gula darah sebelum dan sesudah intervensi. Instrumen penelitian menggunakan alat sphygmomanometer digital Omron untuk mengukur tekanan darah dan Glucose meter easy touch (accu check) untuk mengukur kadar gula darah. Tehnik analisis data menggunakan Mann Whitney Tes dianalisis dengan software SPSS versi 20.00 for windows.

\section{HASIL PENELITIAN}

Penelitian dilaksanakan di Desa Ngesrep, Kecamatan Ngemplak, Kabupaten Boyolali. Subjek yang berpartisipasi dalam ini semuanya berjenis kelamin perempuan.

Tabel 1. Karakteristik Responden

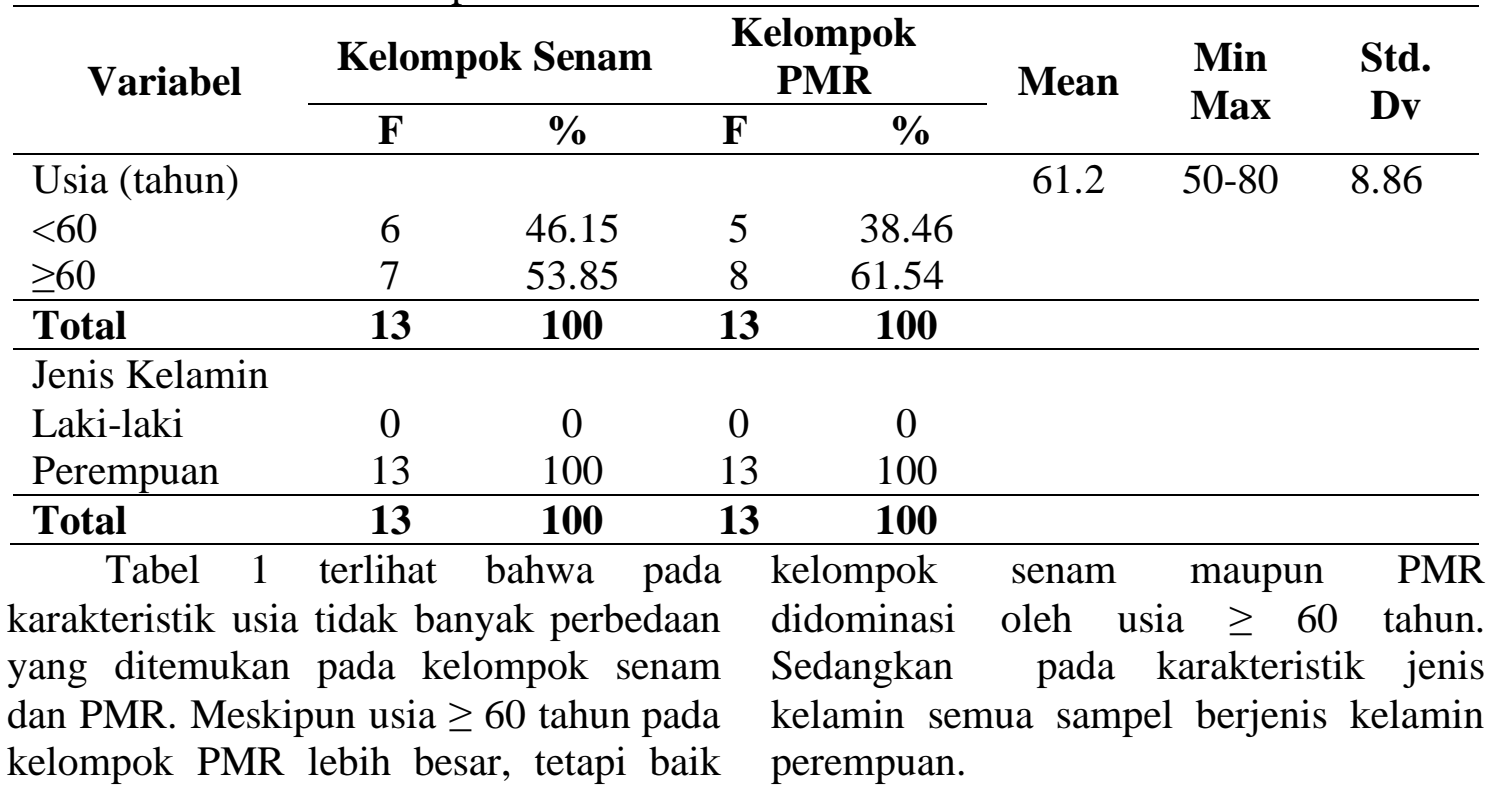

Tabel 2. Rerata Hasil Pengukuran

\begin{tabular}{lcccccccc}
\hline \multirow{2}{*}{ Variabel } & \multicolumn{3}{c}{ Kelompok Senam } & \multicolumn{3}{c}{ Kelompok PMR } \\
\cline { 2 - 9 } & Min & Max & Mean & SD & Min & Max & Mean & SD \\
\hline Pre Tensi & 113 & 182 & 141.38 & 22.01 & 103 & 168 & 148.0 & 19.52 \\
Post Tensi & 112 & 163 & 137.54 & 15.33 & 102 & 178 & 136.46 & 22.27 \\
Pre Gula & 70 & 230 & 123.77 & 41.48 & 88 & 289 & 125.62 & 51.97 \\
Post Gula & 75 & 190 & 113.46 & 28.93 & 65 & 286 & 112.08 & 55.47 \\
\hline
\end{tabular}

Tabel 2 menunjukkan bahwa pada kadar gula darah setelah intervensi lebih kedua kelompok rerata tekanan darah dan rendah dibandingkan sebelum intervensi. 
Tabel 3. Rerata Pengukuran Tekanan Darah dan Gula Darah

\begin{tabular}{clcccc}
\hline Kelompok & \multicolumn{1}{c}{ Variabel } & Pre test & Post Test & Selisih & $\begin{array}{c}\text { P } \\
\text { value }\end{array}$ \\
\hline \multirow{2}{*}{ Senam } & Tekanan Darah & 141.38 & 137.54 & 3.84 & 0.536 \\
& Gula Darah & 123.77 & 113.46 & 10.31 & 0.349 \\
\multirow{2}{*}{ PMR } & Tekanan Darah & 148.0 & 136.46 & 22.23 & 0.030 \\
& Gula Darah & 125.62 & 112.08 & 138.54 & 0.055 \\
\hline
\end{tabular}

Berdasarkan hasil Tabel 3. dapat lebih besar pada kadar gula darah diketahui bahwa terdapat penurunan nilai dibandingkan dengan tekanan darah rerata tekanan darah dan kadar gula darah terjadi pada kelompok senam. Pada sesudah intervensi dibandingkan sebelum kelompok PMR tekanan darah mengalami intervensi. Selisih penurunan nilai yang diperoleh sebelum dan sesudah intervensi, penurunan lebih besar.

Tabel 4. Hasil Uji Hipotesis

\begin{tabular}{|c|c|c|}
\hline Kelompok & $\mathbf{N}$ & p value \\
\hline Gula Darah & 13 & 0.590 \\
\hline Tekanan Darah & 13 & 0.626 \\
\hline
\end{tabular}

dapat diketahui bahwa nilai tekanan darah Desa Ngesrep jumlah penduduk diperoleh $\mathrm{p}=0.626$ dan kadar gula darah perempuan, termasuk lansia, lebih banyak $\mathrm{p}=0.590$. Dengan demikian dapat disimpulkan bahwa senam dan PMR lebih efektif untuk menurunkan kadar gula darah dibandingkan tekanan darah.

\section{PEMBAHASAN}

Sampel yang memenuhi kriteria penelitian ini, untuk kelompok senam memiliki rentang usia yang lebih pendek dibandingkan kelompok PMR. Rentang usia sampel kelompok senam antara 50 70 tahun dengan rerata usia 61 tahun, sedangkan pada kelompok PMR berusia 50 - 80 tahun dengan rerata 60 tahun. Seluruh sampel penelitian, baik untuk kelompok senam maupun PMR, berjenis kelamin perempuan. Dari diskusi dengan kader diperoleh informasi bahwa dalam kegiatan masyarakat, khususnya program posyandu, partisipasi kaum laki-laki memang sangat jarang. Tingkat kehadiran lansia laki-laki dalam kegiatan rutin Posyandu pun sangat rendah. Di sisi lain, dibandingkan penduduk laki-laki.

Hasil pemeriksaan awal sebelum intervensi diketahui bahwa rerata nilai tekanan darah dan gula darah pada kelompok senam sedikit lebih rendah dibandingkan kelompok PMR. Namun demikian, setelah intervensi, justru sebaliknya, pada kelompok senam sedikit lebih tinggi dibandingkan kelompok PMR. Dengan demikian, capaian atau selisih nilai yang diperoleh oleh kelompok PMR lebih besar dibandingkan kelompok senam. Pada kelompok senam, tidak banyak perubahan yang terjadi pada variable penelitian, kemungkinan dapat disebabkan karena aktivitas senam ini telah dilaksanakan secara rutin. Sedangkan pada kelompok PMR, aktivitas ini pernah juga dilaksanakan, tetapi sudah lebih dari satu tahun yang lalu dan tidak pernah dijalankan secara rutin, sehingga justru perubahan yang terjadi pada tubuh karena aktivitas tersebut lebih terasa. Hal 
ini sejalan dengan teori yang mendasarkan pada hubungan dosis-respon latihan, bahwa latihan fisik akan memberikan manfaat kesehatan yang lebih besar pada kelompok yang aktivitas fisiknya lebih rendah.

Hasil penelitian ini menunjukkan bahwa terdapat penurunan tekanan darah dan gula darah pada kelompok senam dan PMR setelah diberikan intervensi. Penelitian serupa yang pernah dilakukan sebelumnya mendukung kesimpulan tersebut.

Cornelissen \& Smart melakukan meta analisis untuk menguji efek latihan ketahanan (endurance), pembebanan dinamis (dynamic resistance), dan kombinasi ketahanan dan pembebanan, serta latihan isometric terhadap tekanan darah pada individu dewasa. Diperoleh hasil bahwa latihan ketahanan dinamis, latihan pembebanan dinamis, dan latihan kombinasi pembebanan dan ketahanan berasosiasi dengan penurunan tekanan darah sistolik dan diastolik.

Dalam artikel clinical review, Ghadieh \& Saab (2015) juga mengemukakan bahwa latihan aerobic intensitas sedang telah terbukti mencegah hipertensi dan membantu memanajemen hipertensi stadium I. Demikian juga latihan pembebanan dinamis, jika dilakukan secara tepat, berkontribusi untuk menurunkan tekanan darah. Hal ini dapat terjadi karena latihan aerobik memfasilitasi mekanisme anti inflamasi melalui sistem saraf simpatetis dan hypothalamic-pituitary-adrenal axis sehingga secara langsung menurunkan tekanan darah (Ghadieh \& Saab, 2015).

Terkait dengan pengaruh latihan fisik terhadap gula darah, Adams (2013) menemukan bahwa latihan aerobik dan pembebanan memperbaiki kontrol glikemik pada diabetes tipe 2. Latihan yang dilakukan berintensitas tinggi (>80\% maximal oxygen uptake, VO2 max) yang dilakukan selama $<15$ menit per sesi. Sejalan dengan itu, Shakil-ur-Rehman, Karimi, \& Gillani (2017) juga menemukan dalam penelitian yang dilakukannya terhadap individu dengan diabetes mellitus tipe 2, bahwa latihan aerobik terstruktur efektif untuk manajemen level glukosa puasa, kontrol glikemik, level plasma insulin dan resistensi insulin pada diabetes tipe 2 .

Mekanisme yang mendasari penurunan level plasma glukosa akibat latihan adalah karena latihan fisik meregulasi transport glukosa oleh GLUT4 proteins dari intraseluler ke plasma membran dan transverse tubules sehingga meningkatkan uptake glukosa oleh otot dan menurunkan level plasma glukosa (Wilmore, Castill, \& Kenney, 2008).

Beberapa penelitian menyatakan bahwa PMR berpengaruh terhadap penurunan tekanan darah. PMR memfasilitasi relaksasi otot dengan menurunkan aktivitas saraf simpatis dan meningkatkan aktivitas parasimpatis sehingga terjadi vasodilatasi diameter arteriol (Muttaqin, 2008). PMR juga efektif untuk menurunkan level gula darah pada diabetes tipe 2 (Avianti, Desmaniarti, \& Rumahorbo, 2006), karena PMR memfasilitasi sekresi hormone endorphin dan mengurangi sekresi hormone edrenalin dan cortisol yang berperan pada penurunan level glucose (Kaviani, et.al, 2014).

\section{KESIMPULAN}

Subjek penelitian berjumlah 26 lansia berjenis kelamin perempuan, dengan rentang usia 50-80 tahun. 
Intervensi senam memberikan pengaruh terhadap penurunan tekanan darah tetapi secara statistik tidak signifikan. Intervensi senam memberikan pengaruh terhadap penurunan kadar gula darah tetapi secara statistik tidak signifikan.

Intervensi PMR memberikan pengaruh terhadap penurunan tekanan darah yang cukup besar dan secara statistik signifikan. Intervensi PMR memberikan pengaruh terhadap penurunan kadar gula darah tetapi secara statistik tidak signifikan. Senam lebih efektif untuk menurunkan kadar gula darah dibandingkan tekanan darah. PMR lebih efektif untuk menurunkan tekanan darah dibandingkan kadar gula darah

\section{DAFTAR RUJUKAN}

Adams, P. (2013). The Impact Of Brief High Intensity Exercise On Blood Glucose Levels. Dovepress Diabetes, Metabolic Syndrome \& Obesity: Target \& Therapy, 6: 113122.

Akhriansyah, M. (2018). Pengaruh Progresif Muscle Relaxation terhadap Penurunan Tekanan Darah pada Lansia. Jurnal Ilmiah Universitas Batanghari Jambi. 19 (1). 11-16.

Anani, S., Udiyono, A., Ginanjar, P. (2012). Hubungan antara Perilaku Pengendalian Diabetes dan Kadar Gula Darah Pasien Rawat Jalan Diabetes Melitus. Jurnal Kesehatan Masyarakat. 1:466-478

Avianti, N., Desmaniarti, Z. \& Rumahorbo, H. (2016). PMR Effectiveness Of The Blood Sugar Patients With Type 2 Diabetes.
Open Journal of Nursing , $6: 248$ 254.

Badan Pusat Statistik. (2017). Statistik Penduduk Lanjut Usia. Jakarta: Badan Pusat Statistik.

Bagheri-Nesami, M., Rafii, F., \& Oskoei, S.F.H. (2010). Coping strategies of iranian elderly woman: a qualitative study. Educational Gerontology, 36: 573-591.

Cornelissen, V. A., \& Smart, N. A. (2013). Exercise Training For Blood Pressure: A Systematic Review \& Meta Analysis. Journal American Heart Association. 2 : e004473 doi : 10.1161?JAHA.112.004473

Fakhrudin, H., \& Khairunisa. (2012). Pengaruh senam jantung sehat terhadap kadar glukosa darah puasa pada lansia di panti sosial \& lansia tresna werdha Natar Lampung Selatan. Medical Journal of Lampung University. ISSN 23373776.

Ghadieh, A.S., \& Saab, B. (2015). Evidence For Exercise Training In The Management Of Hypertension In Adults. Canadian Family Physician. Vol 61, March.

Kaviani, M., Bahoosh, N., azima, S., Asadi. N., Sharif, F. \& Sayadi,M. (2014). The Effect Of Relaxation On Blood Sugar \& Blood Pressure Changes Of Women Eith Gestational Diabetas: A Randomized Control Trial. Iranian Journal of Diabetes \& Obesity . 6 (1). 
Kementerian Kesehatan RI. (2017). Analisis lanjut usia di Indonesia. Jakarta: Pusat Data dan Informasi.

Kementerian. (2018). Profil Kesehatan Indonesia 2017. Jakarta: Pusat Data dan Informasi.

(2018). Riskesdas 2018. Jakarta: Balitbangkes.

Kumutha, V., Aruna, S., \& Poongodi, R. (2014). Effectiveness Of Progresive Muscle Relaxation Technique On Stress Blood Pressure Among Elderly With Hypertension. Journal of Nursing and Health Science. 3 (4). e-ISSN 2320-1959.

Muttaqin, A. (2008). Buku Ajar Asuhan Keperawatan Klien Dengan Gangguan. Sistem Imunologi. Jakarta: Salemba Medika.

Physical Activity Guidelines Advisory Committee. (2008). Physical Activity Guidelines Advisory Committee Report. Washington DC : Departement of Health and Human Services.

Pusdatin Kemenkes RI. (2014). Hipertensi. Jakarta: Infodatin. . (2016). Situasi lanjut usia di Jakarta. Jakarta: Infodatin

Ramadhani, A., Sapulete, I. M., \& Pangemanan, D.H.C. (2016). Pengaruh Senam Lansia Terhadap Kadar Gula Darah Pada Lansia Di BPLU Senja Cerah Mando. Jurnal e-Biomedik.4(1).
Shakil-ur-Rahman, S., Karimi, H., \& Gillani, S.A.(2017). Effects Of Supervised Structured Aerobic Exercise Training Program On Fasting Blood Glucose Level, Plasma Insulin Level, Glycemic Control, And Insulin Resistance In Type 2 Diabetes Mellitus. Pakistan Journal of Medical Science. 33(3).

Siswanti, H \& Kulsum, U.(2019). Progresif Muscle Relaxation Terhadap Perubahan Kadar Glukosa Darah Pada Pasien Diabetes Melitus. Jurnal Ilmu Keperawatan dan Kebidanan. 1 (10). 206-212.

Trisnanto. (2016). Pengaruh Senam Lansia Terhadap Penurunan Tekanan Darah Pada Lansia Dengan Hipertensi Grade I-II Di Posyandu Lansia Kecamatan Brogo, Kabupaten Nganjuk. Jurnal Nusantara Medika. 1 (1), 79-88.

Tulak, G.T. \& Umar, M. (2017). Pengaruh Senam Lansia Terhadap Penurunan Tekanan Darah Pada Penderita Hipertensi Di Puskesmas Wara Lopo. Jurnal Perspektif. 2(1). ISSN 2355-6538.

United Nations Departement of Economic and Social Affairs Population Division (2013). World Population Ageing 2013.New York. Diunduh tanggal 16 Februari 2018 dari http://www.un.org/en/development/ desa/population/publications/pdf/ag eing/WorldPopulation Ageing2013.pdf.

Wilmore, J. H., Costill, D.L., \& Kenny, W.L. (2008). Physiology Of Sport 
40 Jurnal Keterapian Fisik, Volume 5, No 1, Mei 2020, hlm 1-61

And Exercise (4th Ed). Illionois: Human Kinetics.

Zulaikha. (2016). Efektivitas Senam Senam Lansia Pada Penurunan Tekanan Darah Pada Lansia Hipertensi Di Wilayah Kerja Puskesmas Bulu, Kab. Sukoharjo.Naskah Publikasi UMS Fakultas Kesehatan Masyarakat. 